\title{
CHANGES IN TEACHERS' REFLECTION AFTER LESSON STUDY PROCESS
}

\author{
${ }^{1}$ Tan Saw Fen, ${ }^{2}$ Lim Chap Sam \& ${ }^{3}$ Chew Cheng Meng \\ ${ }^{1}$ School of Education, Languages and Communications \\ Wawasan Open University, Penang, Malaysia \\ ${ }^{2,3}$ School of Educational Studies \\ Universiti Sains Malaysia, Penang, Malaysia \\ ${ }^{1}$ Corresponding author: sawfen@gmail.com
}

\begin{abstract}
Purpose - This qualitative study explores if there were any changes in teachers' reflection in terms of content and levels after participating in five lesson study cycles.

Method - Case study method was employed in this study. Six mathematics teachers from a primary school participated in this study. They set up a lesson study group and conducted five lesson study cycles. In each lesson study cycle, the lesson study team members plan, teach and observe a research lesson. Qualitative data was collected through participatory observation, reflection sessions, collection of artefacts and interviews.
\end{abstract}

Findings - Analysis of data revealed that there were some slight and slow changes in the teachers' reflection as they progressed from the first to the fifth reflection sessions. These changes included: (1) teachers' reflection became more specific and in-depth; (2) teachers' reflection about the pupils' learning became more in-depth; (3) teachers reflected from pupils' perspectives; and (4) teachers reflect athigher level of reflection.

Significance - The study revealed that the criteria of lesson study, collaborative and classroom observation, made it feasible in promoting teachers' reflection. The educators could employ lesson study as an approach to promote teachers' reflection. However, the effectiveness of lesson study in promoting teachers' reflection is 
affected by the number of lesson study cycles being carried out and the presence of the knowledgeable others.

Keywords-in-service teacher, lesson study, levels of reflection, mathematics teacher, reflection

\section{INTRODUCTION}

The use of reflection as teacher professional development is getting popular (Suratno \& Iskandar, 2010; O'Sullivan, 2002) because teachers would be able to understand the complex nature of teaching and learning in their classroom as they reflect (Zeichner \& Liston, 1996). As they reflect, teachers learn from and enhance their teaching practices. Furthermore, reflection can also be a self-evaluation where it assists the teachers to recognise their own strengths and weaknesses (Boon, 2002). As a result, the teachers see the needs and directions of finding new ideas from other sources to improve their teaching practice (McIntyre, 1993). Ultimately, reflection encourages the teachers to involve more actively in professional development (O'Sullivan, 2002). According to Scales (2008) and Hassett (2000), reflection is the master key of effective teachers because it underpins other characteristics of effective teachers, like flexible and willing to adapt and change to meet students' needs; learn from a variety of models; and never stops learning. Similarly, Braun and Crumpler (2004) also recognized the importance of reflection as they criticized that those teachers who do not reflect upon their practices "will likely to teach as they were taught and, thus, ineffective teaching strategies... will be replicated" (p. 61). Therefore, being able to reflect deeply and critically is crucial to teachers.

In Malaysia, reflection was introduced to teacher training program when the clinical supervision was implemented in the student teaching component in year 1989. Then, in year 1999, Malaysian Ministry of Education (1999) made it compulsory for all the inservice teachers to write their reflection in their lesson plan after their lessons. The teachers were expected to reflect on to what extent they have achieved their teaching and learning objectives. However, the task may not really support the teachers to reflect deeply and critically. 
Review of literature shows that not many studies were done on Malaysian teachers' reflection. Those studies focused on both pre-service teachers (e.g. Aizan Yaacob, Walters, Ruzlan Md Ali, Sarimah Shaik Abdullah \&Walters, 2014; Nooreiny Maarof, 2007) and in-service teachers (e.g. Siti Mistima Maat \& Effandi Zakaria, 2010; Tee, 2007; Suraya Sulyman, 2005). These studies reported that the participating teachers only described the incidents happened in the classroom and they could not identify the right action to be taken (Siti Mistima Maat \& Effandi Zakaria, 2010). In addition, their reflection was narrow (Suraya Sulyman, 2005). These studies also reported that the participating teachers' reflection was descriptive where they just described the incidents that happened during the lesson. Hatton and Smith (1995) critiqued that productive reflection which helps the teachers to develop a complex view of their teaching would not be promoted if they merely describe the teaching and learning processes in the classroom. Their statement was supported by Davis (2006). Therefore, it is crucial to promote reflection among the teachers.

\section{Reflection}

The notion of reflection was defined by John Dewey (1993) as "active, persistent, and careful consideration of any belief or supposed form of knowledge in the light of the grounds that support it and the further conclusion to which it tends" (p. 9). Several approaches have been used to promote teachers' reflection, such as reflective journal writing (e.g. Nooreiny Maarof, 2007), action research (e.g. O'Sullivan, 2002) and collaborative reflection (e.g. Hindin et al., 2007). Reflective journal writing supports individual reflection. Teachers make reflection based on their own observation. Then, they analyse their observation based on their experience. Nevertheless, the teachers' observation might be limited because many incidents happen in the classroom simultaneously. The teachers might overlook some incidents in the classroom when they are teaching. Their reflection will be even more narrow if they have not acquired the observation skills. Besides, when the teachers are reflecting alone, they, especially the novice teachers might be lack of ideas in taking suitable action to solve their problem or improve their practice. Therefore, the potential of individual reflection in helping the teachers to learn from their teaching might be limited. 
After realizing the limitations of individual reflection, some educators (e.g. Hindin et al., 2007; Glazer et al., 2004) promoted collaborative reflection. In a study conducted by Hindin et al. (2007), teachers who taught the same topics met frequently to discuss, share result and consult each other. Whereas, in another study done by Glazer et al. (2004), the participating teachers brainstormed the issues or challenges they wanted to discuss, then, they reflected and discussed the issues together. In both these studies (Hindin et al., 2007; Glazer et al., 2004), the teachers engaged in collaborative reflection, where they reflected and exchanged knowledge, experience as well as ideas. The collaborative reflection eventually improved their teaching quality. The findings were coherent with statement by Van Gyn (1996, as cited in Glazer et al., 2004) that the teachers are more likely to be reflective when they are working collaboratively if compared with working individually

Nonetheless, in the collaborative reflection setting as discussed in the previous paragraph, the teachers shared their teaching issues verbally. The teachers understood and discussed based on their peers' oral description. So, the information the teachers received might be constrained by the observation and describing skills of the teachers who described the issues. Thus, there is a need to include the classroom observation to the collaborative reflection. There are three main advantages of including classroom observation to the collaborative reflection: (1) as the observing teachers observe another teacher's lesson, they are able to share a clearer or more comprehensive picture of the pupils' learning; (2) the teacher who teaches the lesson would be able to realise their own weaknesses or strengths from the feedback given by the observing teachers; and (3) the observing teachers learn as they observe the teaching of another teacher. In sum, collaborative reflection and classroom observation promotes teachers' reflection. Lesson study is a professional development model that has fulfilled these two criteria.

\section{Lesson Study}

Lesson study is a teacher professional development model originated from Japan. It is a long-term teacher-led professional learning. In the lesson study process, a group of teachers plan, conduct and reflect on research lesson collaboratively and systematically (Wang-Iverson \& Yoshida, 2005). Research lesson refers to the lesson taught by a 
teacher to a group of pupils, based on the lesson plan developed by the lesson study group. During the research lesson, other members of the lesson study group observe and collect the data of the pupils' learning during the lesson. Reflection session was conducted after the research lesson, where the members of the lesson study group reflect based on the data they have collected during the research lesson.

In this study, lesson study was chosen as an approach to promote teachers' reflection because it fulfills the characteristics of professional development that promotes teachers' reflection, as discussed in the previous section, which are collaborative reflection and classroom observation. In lesson study, the lesson study group members observe the research lesson taught by a teacher in the lesson study group based on the lesson plan they have prepared. After the research lesson, they reflect collaboratively. They share their observation and reflection during the reflection sessions. In some cases, knowledgeable others are invited to observe the research lesson and give the final comments during the reflection session.

Lesson study drew the attention of the world after the publication of The Teaching Gap: Best Ideas from the World's Teachers for Improving Education in the Classroom in year 1999. Since then, lesson study is spread to many other countries. Several researchers and educators adopted or even adapted lesson study in their countries (e.g. Suratno, 2012; Yoshida, 2012; Chiew, 2009). As a result, many studies related to lesson study were conducted. At the beginning stages, most of the studies conducted focused on the feasibility of lesson study in their culture or country (e.g. Cajkler et al., 2014; Chiew, 2009). After believing in the potential of lesson study, researchers tried to use lesson study as a platform to achieve some pedagogical goals. For instance, Ong (2010) used lesson study as an approach to help the participating teachers to enhance their questioning skills. Then, some researchers studied on the process of lesson study. For instance, Takahashi (2014) researched the comments given by three highly respected knowledgeable others in Japan. While some researchers focused on the impact of lesson study on the participating teachers and pupils, like the change of teachers' observation skills (Myers, 2012), the change of teachers' knowledge for teaching mathematics (Suh \& Seshaiyer, 2014; Meyer \& Wilkerson, 2011), and the pupils' learning as they engaged in the lesson study process (Mak, 2016; Lasut, 2013). 


\section{Teachers' Reflection in Lesson Study}

As advocated by Suratno and Iskandar (2010), reflection is the heart of lesson study. The teachers are reflecting when they are planning, doing and reflecting. Suratno and Iskandar (2010) characterized the reflection in lesson study into three types, namely prospective analysis, situational analysis and retrospective analysis.

(i) Prospective analysis

The teachers conduct prospective analysis when they are at the planning stage. They analyse the pupils' learning obstacles and predict their learning, then they developed hypothetical learning trajectory (HLT).

\section{(ii) Situational analysis}

The teachers apply situational analysis when they are at doing stage. The teacher who teach the research lesson think, reflect and act directly to the real class situation. The observing teachers think and reflect as if they are teaching. They compare the actual learning trajectory (ALT) with the HLT.

(iii) Retrospective analysis

The teachers apply retrospective analysis at the reflecting stage. They analysis the HLT and ALT. They also analyse the relationship between the teachers' teaching and the pupils' learning, then seek for alternative HLT for future teaching.

Although reflection occurs in all the lesson study steps, but, this study only focused on the reflection in the reflecting stage because the teachers were reflecting together with the knowledgeable others during the reflection session. Fernandez et al. (2003) commented that the presence of knowledgeable other enriches the discussion. Therefore, this study intended to explore how the teachers' reflection changes (if any) during the reflection sessions.

\section{Theoretical Framework}

Based on situated learning theory (Lave \& Wenger, 1991), there are novices and experts in the community of practice. As the novices 
participate in the community of practice, they communicate with other novices and experts in the community. Ultimately, they internalize the culture and practice of the community and become experts.

In a lesson study group (community of practice), the teachers (novice) are not familiar with the concept of reflection in lesson study when they first started to conduct the lesson study process. As they conduct the lesson study cycles, they interact with the other teachers and knowledgeable others in the lesson study group and they learn how to reflect. After several lesson study cycles, they become able to reflect like an expert.

Some earlier studies (e.g. Chiew, Mohd Hasani Dali \& Lim, 2016; Burghes \& Robinson, 2009; Chiew, 2009; White \& Lim, 2007, 2008) proposed that lesson study probably could promote teachers' reflection. Thus, some studies (Chikamori et al., 2013; Myers, 2012; Posthuma, 2012; Tosa, 2014) have been done to explore the teachers' reflection in lesson study. These studies focused either on teachers' content of reflection (Tosa, 2014; Chikamori, 2013; Posthuma, 2012) or levels of reflection (Myers, 2012). It was found that there are four major categories of teachers' content of reflection, (Tosa, 2014; Chikamori, 2013; Posthuma, 2012) which included (i) teacher and teaching, (ii) pupils and learning, (iii) classroom context, and (iv) others. Teacher and teaching encompasses the teacher's personality, teacher's strengths or weaknesses, teacher's teaching practices or teaching style, teacher's questioning techniques, and achievement of learning objectives. Meanwhile, the second category, pupils and learning included students' personality and students' learning. The third category, classroom context referred to the classroom setting, classroom management and classroom size. Lastly, the language used, the textbook and the examination were under the category of other.

Myers (2012) employed the levels of reflection advocated by Hatton and Smith (1995) in categorizing the levels of teachers' reflection. According to Hatton and Smith (1995), there are four levels of reflection, namely descriptive story, descriptive reflection, dialogic reflection and critical reflection. Descriptive story is not considered reflective because at this level, the teacher merely describes the events without providing reasons and justifications. At descriptive 
reflection level, the teacher attempt to provide the reasons and justifications besides reporting the incidents. Dialogic reflection refers to "discourse with self and exploring the experience, events and actions using qualities of judgements and possible alternatives of explaining and hypothesising" (Hatton \& Smith, 1995, p. 48). The teachers reflect from several perspectives at this level of reflection. Lastly, teachers reflect at critical reflection level are aware that events or actions are affected by multiple historical and socio-political context. So, they take into consideration of broader historical, social and/or political context when they give reasons or justification to the events or actions. Myers (2012) found that the 20 participating preservice teachers' reflection was at low level, descriptive writing and descriptive reflection. There was no critical reflection found in those teachers' individual reflection and group reports.

These studies (Tosa, 2014; Chikamori, 2013; Posthuma, 2012; Myers, 2012) only reported the content and levels of teachers' reflection, they did not discuss the changes in teachers' reflection. As commented by Takahashi (2011), the impact of lesson study is only visible after the teachers conducted multiple lesson study cycles. Perhaps, due to the limited number of lesson study cycles conducted, for example, Posthuma (2011) involved four cycles while Myers (2012) only one cycle. Thus, in this study, we proposed to conduct at least five lesson study cycles, so as to explore any changes in teachers' reflection.

\section{METHOD}

\section{Participants}

The lesson study group was set up in a small scale primary school which has only a headmaster, 10 teachers and 138 pupils. Six mathematics teachers from this school participated in this lesson study group. Table 1 displays the information of the six participating mathematics teachers.

The lesson study group was started by four teachers, who were Jia Zhe, Rui Ern, Wei Jie and Li Li. However, Wei Jie was transferred to another school after the third lesson study cycle. So, he only participated in the first three lesson study cycles. Shu Mei and Kai Yan were new mathematics teachers who joined the school when the 
project was conducted. The headmaster invited them to join in the lesson study group. Therefore, Shu Mei and Kai Yan participated since the fourth lesson study cycle. Jia Zhe, Rui Ern, Li Li, Shu Mei and Kai Yan were teaching mathematics at different levels in the school. Meanwhile, Wei Jie was teaching tutoring class for students from Year 1 to 6 in the school. The tutoring class was conducted for the students who did not perform well in the mathematics.

Table 1

Background Information of the Participants

\begin{tabular}{cccc}
\hline $\begin{array}{c}\text { Participant } \\
\text { (pseudonym) }\end{array}$ & Gender & $\begin{array}{c}\text { Teaching } \\
\text { Experience (year) }\end{array}$ & $\begin{array}{c}\text { Mathematics } \\
\text { Teaching (level) }\end{array}$ \\
\hline Jia Zhe & Male & 1 & Year 4 \\
Rui Ern & Female & 5 & Year 5 \\
Wei Jie & Male & 4 & (Year 1-6) Tutoring classes \\
Li Li & Female & 7 & Year 1 \& 6 \\
Shu Mei & Female & 10 & Year 2 \\
Kai Yan & Female & 6 & Year 3 \\
\hline
\end{tabular}

The lesson study group was started by four teachers, who were Jia Zhe, Rui Ern, Wei Jie and Li Li. However, Wei Jie was transferred to another school after the third lesson study cycle. So, he only participated in the first three lesson study cycles. Shu Mei and Kai Yan were new mathematics teachers who joined the school when the project was conducted. The headmaster invited them to join in the lesson study group. Therefore, Shu Mei and Kai Yan participated since the fourth lesson study cycle. Jia Zhe, Rui Ern, Li Li, Shu Mei and Kai Yan were teaching mathematics at different levels in the school. Meanwhile, Wei Jie was teaching tutoring class for students from Year 1 to 6 in the school. The tutoring class was conducted for the students who did not perform well in the mathematics.

The management was very supportive. The teachers were free to schedule their research lessons and reflection sessions during the school time. Furthermore, the teachers were very committed. They stayed back after the school dismissed to have discussion and lesson plan refining sessions. 


\section{Knowledgeable Others}

There were three knowledgeable others in this lesson study group. They were two lecturers and a postgraduate student from a local university. They played the roles as knowledgeable others as well as researchers to collect data. As knowledgeable others, they played the roles of (1) bringing new knowledge from research and the curriculum; (2) showing the connection between the theory and the practice; and (3) helping others learn how to reflect on teaching and learning, as they are the ones who give the final comments (Takahashi, 2014). Besides, the knowledgeable others also guided the teachers during the whole process of lesson study.

Among the three knowledgeable others, only one of them, Xiao Ling, was experienced in lesson study. She has conducted several research projects related to lesson study. Meanwhile, another two knowledgeable others, Pei Qi and Hui Hui, learnt about lesson study through reading. Yet, all of them were content experts in mathematics teaching.

\section{The Lesson Study Process}

After the lesson study group was set up, they started their first lesson study cycle by preparing a lesson plan. Jia Zhe volunteered to teach the first research lesson to a group of pupils. The topic of the lesson was "Conversion of time and calculation of interval of time" for Year 4 pupils. During the research lesson, all the other members of the lesson study group observed the research lesson. Each of them was given an observation sheet, which guided them how to observe during the research lesson. They filled in the observation sheets when they were observing. After the research lesson, all the members gathered and made their reflection. The observers referred to the observation sheets they wrote when they were reflecting in the group. The reflection sessions were recorded for analysis purpose. The researchers participated in all the steps of the lesson study cycle.

The lesson study group continued to carry out another four lesson study cycles. The second and third research lessons were taught by Rui Ern. The topics of both research lessons were "Calculation of volume" for Year 4 and Year 5 pupils respectively. Meanwhile, the fourth research lesson taught by $\mathrm{Li} \mathrm{Li}$ was related to "Proper fraction and equivalent fraction" for Year 3 pupils. Lastly, the fifth research 
lesson was about "Improper fraction and mixed number" for Year 4 pupils. The last research lesson was taught by Kai Yan. After the five lesson study cycles, the researchers interviewed all the participating teachers individually. The interviews aimed to explore the teachers' perceptions about the lesson study and reflection.

\section{Methods of Data Collection}

In this study, qualitative data was collected through:

\section{a. Reflection sessions}

The lesson study group conducted five reflection sessions. All the reflection sessions were video recorded and transcribed verbatim for analysis.

\section{b. Collection of artefacts}

The artefacts collected included observation sheets, lesson plans, worksheets and teaching materials used in during the five research lessons.

\section{c. Interview}

After the lesson study group completed five lesson study cycles, the researchers interviewed all the participating teachers individually to explore their views about lesson study in general and the reflection session in the lesson study.

\section{d. Participatory observation}

In this study, the researchers played dual roles: as participants, they played the roles of knowledgeable others. They guided the teachers about the concept and process of lesson study. They also participated in all the lesson study cycles and gave final comments during the reflection sessions. As researchers, they observed the teachers' reflection, actions, commitment and behaviour during the lesson study cycles. They also took rigorous field notes after the observation. 


\section{Data Analysis}

All the qualitative data collected including videos of reflection session, observation sheets, lesson plans, teaching materials and field notes were imported into NVivo, a software for analyzing qualitative data. The videos were first transcribed verbatim, and then divided into segments. A segment means the part of the transcript which was related to a theme or topic of reflection. The segment ended when the topic of conversation changed. The length of a segment ranges from a phrase or an utterance from a person to several utterances from different persons. These segments were then coded to become the themes of reflection, such as pupils' learning, teaching strategy and instructional content.

These segments were also coded to the respective levels of reflection as suggested by Hatton and Smith (1995), namely descriptive story, descriptive reflection, dialogic reflection and critical reflection. The findings of reflection sessions were triangulated with the observation sheets, lesson plans and field notes. Later, the coding was compared across the five lesson study cycles to explore any changes (if there is) in the teachers' reflection.

\section{RESULTS}

Analysis of the data shows that after the five LS cycles, there were four changes in the teachers' reflection. These changes are: (1) teachers' reflection became more specific and in-depth; (2) their reflection about pupils' learning became more focus and in-depth; (3) They moved to reflect from pupils' perspectives, and (4) They were able to reflect at a higher level.

\section{(1) Teachers' Reflection Became More Specific and In-depth}

There were eight themes emerged from the teachers' reflection: pupils' learning, pupils' behaviour, teaching strategy, time management, teacher's personality and behaviour, instructional content, mathematical task, as well as teaching materials. Figure 1 displays the percentages of utterances of the eight themes across the five LS reflection sessions. 


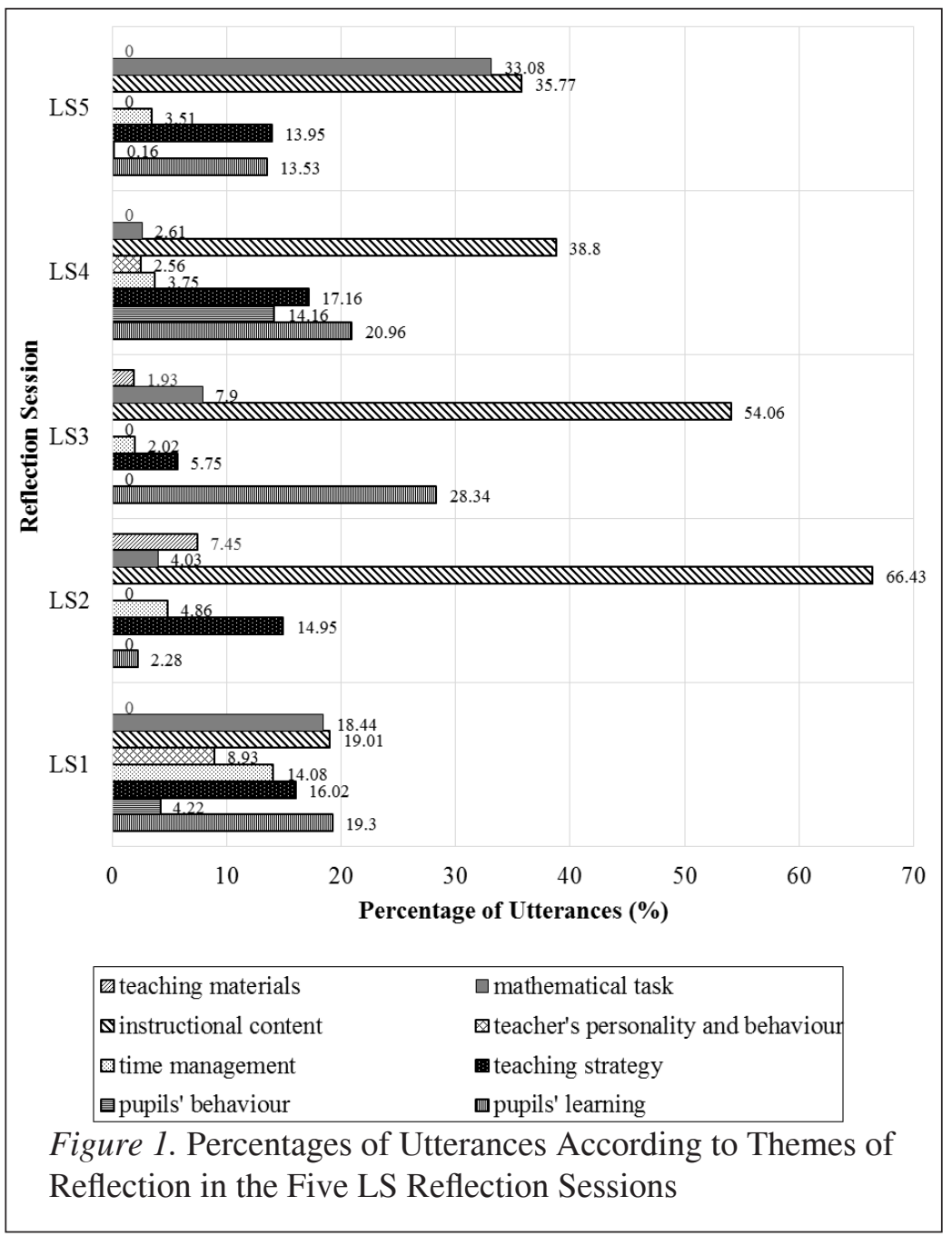

As shown in Figure 1, during the first reflection session (LS1), the themes reflected by the teachers were scattered among the seven themes except teaching materials. The percentages of utterances of these seven themes range from 4.22 percent to 19.31 percent. The teachers reflected about many aspects of the research lesson, but their reflections were relatively shallow. In the second and third LS reflection sessions, more than 50 percent of the utterances were related to the instructional content, which were 66.43 percent and 54.06 percent respectively. It was because one of the knowledgeable others, Pei Qi was very concerned about the instructional content, 
she commented on the instructional content delivered and the development of the mathematical concept. In both reflection session, more than 85 percent of her utterances were related to instructional content. Her reflection has affected other members in the lesson study group, especially RL and Rui Ern, who also discussed on the same issue. This finding supports the results reported by Ono et al. (2013) that the content of reflection during the reflection sessions could be influenced by some key participants who might set the direction of the reflection for the whole group.

However, the teachers' reflection was observed to become more focused and in-depth at the later cycles of lesson study. The themes of reflection in the last two reflection sessions were focused to only four themes of reflection: pupils' learning, pupils' behaviour, teaching strategy and instructional content. Meanwhile, during the final LS reflection session, they reflected mainly on the pupils' learning, teaching strategy, instructional content and mathematical task. Furthermore, the teachers were able to analyse the complex nature of the research lesson by viewing the relationship between the themes of reflection. For example, during the fifth reflection session, Kai Yan described that the pupils were not able to answer the questions she gave in the worksheet correctly. Figure 2 exhibits a question in the worksheet. The pupils were expected to move the portions in the picture in order to get a full piece of the diagram and identify the mixed number. The teachers related the pupils' problem in answering this question (pupils' learning) with the instructional content and mathematical task. Kai Yan related to the example she discussed during the research lesson, as shown in Figure 3. She explained, "maybe because the examples I gave were too simple, 1 in the mixed number was represented by a full shaded diagram. But, for the questions in the worksheet, the pupils need to think deeper in order to get the correct answer" (LS5). Her statement was supported by Shu Mei, she elaborated that the mathematical task was not suitable because "these questions are considered questions that enhance the pupils' understanding by making them to think deeply" (LS5). Similarly, Rui Ern related the mathematical task with the pupils' learning, she said "it's too difficult for them to answer this kind of question immediately after the pupils learn the concept of mixed number and improper fraction" (LS5). 


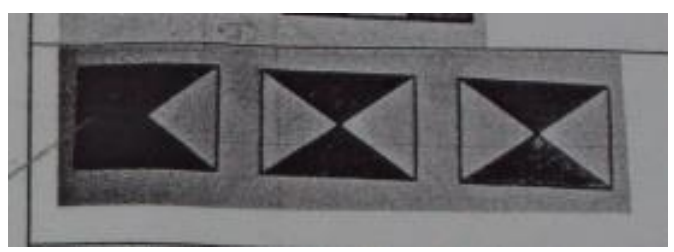

Figure 2. Question in the worksheet

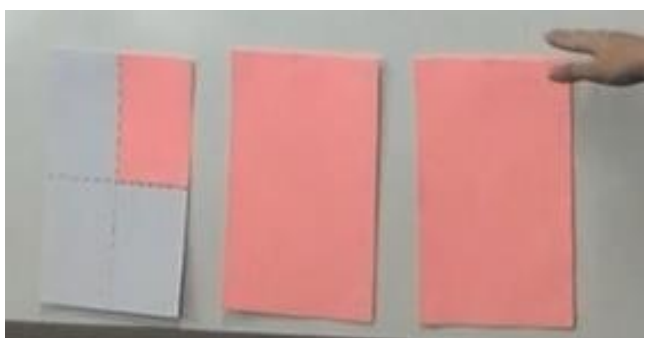

Figure 3. Example discussed by the teacher

\section{(2) Teachers' Reflection about Pupils' Learning Became More Focus and In-depth}

The teachers reflected about the pupils' learning in the research lesson in all the five LS reflection sessions. At the earlier LS cycles, their reflection about the pupils' learning appeared to be superficial as they just described whether they pupils were able to understand the concept of answer the questions correctly. For instance,

"I think they did not understand the 'Golden Hour'. Then, when talking about 72 hours, golden 72 hours is equivalent to how many days, they were able to calculate it. Next, one week is equal to how many hours, they need to know there are seven days in one week, so they faced problem in solving that question. After that I asked two weeks is equivalent to how many hours, they were able to calculate, but they need some guidance" (Jia Zhe, LS1). 
"I think the pupils did not understand the concept, they did not understand when they were assembling the building" (Li Li, LS2).

Comparatively, at the later cycles of lesson study, the teachers' reflection about the pupils' learning became more focus and indepth. They were able to pinpoint the pupils' misconception which might have caused the pupils to answer the questions wrongly. For instance, Figure 4 presents a question in the worksheet which asks the pupils to to identify the improper fraction of the picture. Instead of simply stating the pupils' understanding at superficial level, Kai Yan elaborated the pupils' possible misconception as:

"the pupils did not know the way of identifying the denominator, they counted [the total number of portions], for example, there were three circles... the denominator should be six, but [the pupils] added up all the portions, [so their denominator became 18]. The pupils have not mastered the concept of denominator yet" (Kai Yan, LS5).

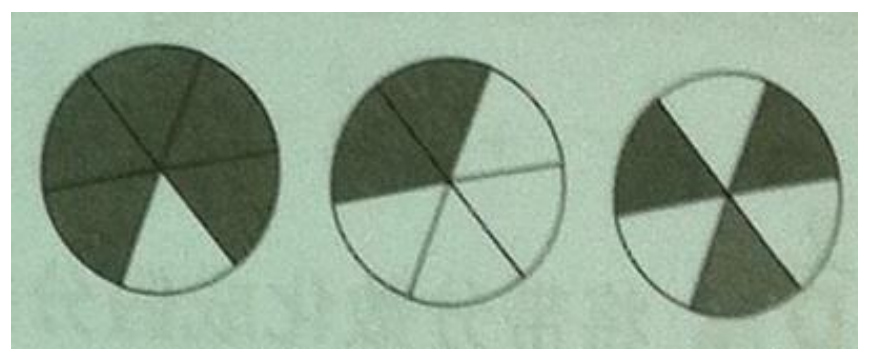

Figure 4. Question in the worksheet

Hence, it was noticed that the teachers' reflection about the pupils' learning became more in-depth as they progressed to the fifth lesson study cycles.

\section{(3) Reflecting from the Pupils' Perspectives}

During the earlier cycles of LS, the teachers seemed to reflect from their own perception of what is an effective teaching should be. They gave comments such as: 
"I want to praise him [Jia Zhe, the teacher teaching the research lesson] for admitting his mistakes... because we, as teacher, after we design an idea, sometimes we change the idea on the spot, so got mistakes, he changed immediately, this is correct [attitude]" (Rui Ern, LS1)

"The [induction set] was interesting, because the teacher used a big dice" (Jia Zhe, LS2)

Jia Zhe's comment implies that to make the induction set interesting, it is advisible for teachers to use appropriate teaching tools such as a dice. However, at the later cycles of lesson study, we observed that the teachers' reflection have moved to reflect from their pupils' perspectives. They gave comments based on their pupils' learning and behaviour. For instance, during the fourth research lesson, the pupils were given group work. After they have completed, the teacher discussed the answers to each question one by one. During the reflection session, teacher, Rui Ern critiqued the teacher's teaching, "actually we don't have to mark the answers one by one, the pupils already felt bored" (Rui Ern, LS4). Rui Ern's comment shows that she has focused her observation to the pupils' behavior during the classroom teaching. The reflection session then followed with suggestion from one of the knowledgeable other, Hui Hui that perhaps "getting the [four groups of pupils] exchanged their answers, and ask them to mark the answers written by other group" (Hui Hui, LS4).

Besides, there was another similar example in the fifth LS cycle. The reflection was started by one of the knowledgeable others, Hui Hui who pointed out that some pupils assumed the fractions "with the same denominator" are equivalent fraction. Then, the teachers gave suggested to refine the lesson plan based on this pupils' learning, she said, "making comparison, $1 \frac{1}{2}$ and $\frac{3}{2}$ are equivalent, then show $\frac{4}{2}$, [ask the pupils], are they equivalent? Although their denominators are the same, they are not equivalent" (Kai Yan, LS5). In sum, the teachers have shifted their perspectives when they were reflecting at the later stages of lesson study, they reflection from the pupils' perspectives.

\section{(4) Moved to Reflect at a Higher Level}

In this study, teachers' reflections were also coded to the four levels of reflection as suggested by Hatton and Smith (1995), 
namely descriptive story, descriptive reflection, dialogic reflection and critical reflection. Figure 5 displays the percentages of the levels of teachers' reflection in the five reflection sessions. At the earlier LS cycles, more than $50 \%$ of the teachers' reflection was at descriptive story level. At this level, the teachers merely described what was happening during the observed research lesson. They did not elaborate or gave any further analysis in their reflection. For instance,

"the pupils' responses were very good" (Rui Ern, LS1).

"only the teacher was talking, the pupils did not talk. This is my drawback, I always forget to give the pupils chance to speak" (Rui Ern, LS2)

However, as shown in Figure 5, the percentage of reflection at descriptive story level decreased as the teachers progressed to the fifth LS reflection session, from $54.5 \%$ (LS1) to $17.94 \%$ (LS5). .

In contrast, the percentages of reflection at the dialogic level were low at the beginning cycles of lesson study, but gradually increased from $27.69 \%$ (LS1) to $75.08 \%$ (LS5). The increasing percentage at this dialogic level, implies that the teachers have acquired the skills of giving alternative ways to improve their lesson. The teachers are now able to analyse their teaching from several different perspectives.

For example, during the last LS cycle, the teachers found that the pupils faced problem in determining the denominator of improper fractions and mixed number. The pupils added up all the portions in the pictures to get the denominator of the fractions. When the teachers were discussing about this problem, they analysed the problem from three perspectives. First, Rui Ern perceived that it was because "the pupils have not mastered the basic concept of the fraction" (Rui Ern, LS5). She pointed that it was caused by the pupils' prior knowledge. However, Li Li and Kai Yan disagreed with her and argued that, "no, [the pupils] have mastered the basic concept of fraction" (Kai Yan, LS5). Instead, Kai Yan linked the problem with the pupils' learning in their previous lesson, which taught about the concept of proper fraction. She articulated, "Could it be because the pupils were confused with the concept taught in the 


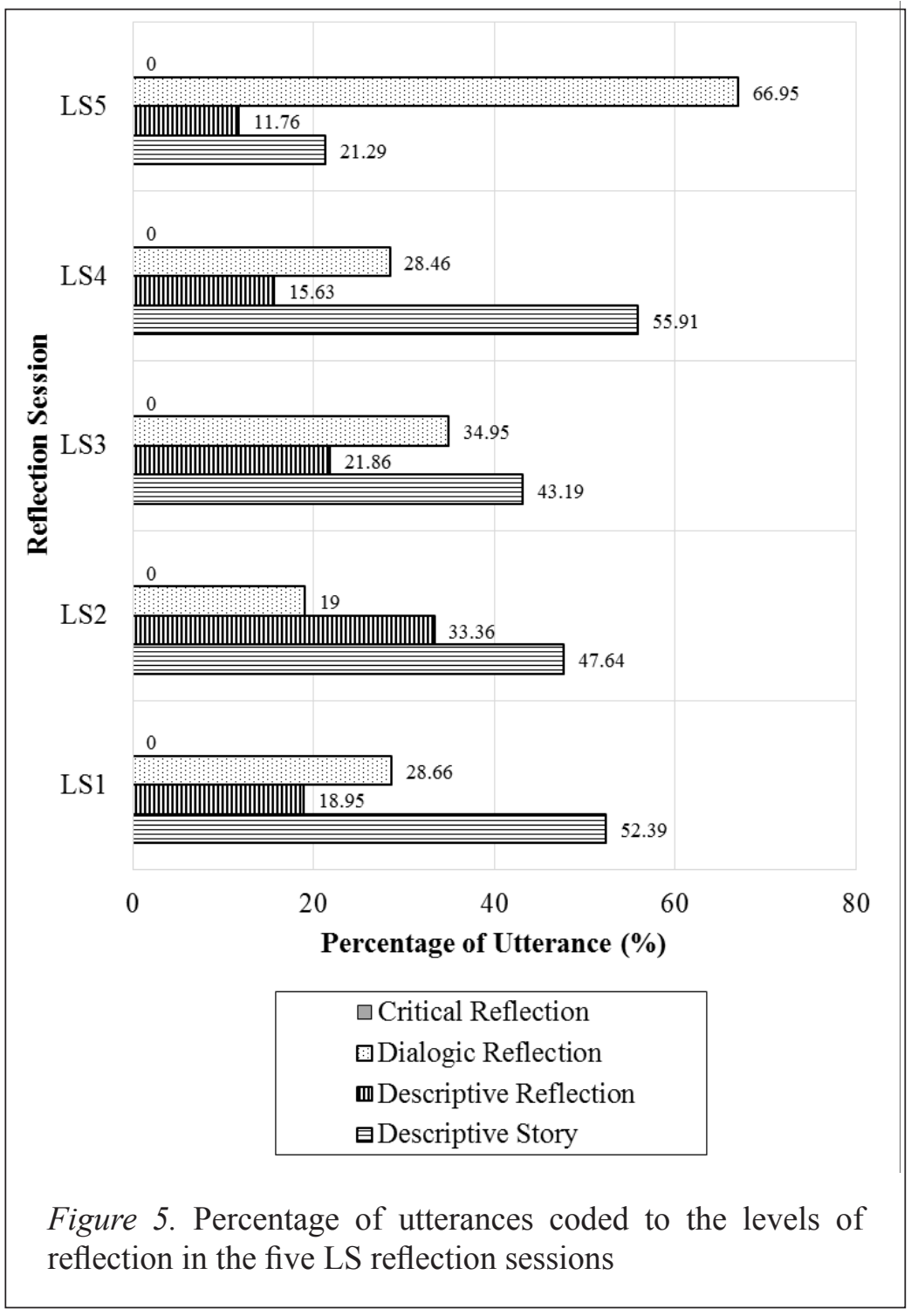

previous lesson? Because in that lesson, we taught them to count all the portions" (Kai Yan, LS5). However, her point was rejected by Li $\mathrm{Li}$, who taught the previous lesson, she said, "I only used one paper at that time, I drew all the portions on the same paper" (LS5).

After much argument, the teachers were able to view the problem from another perspective. They concluded that the pupils' 
misconception might have caused by the instructional content taught in the previous research lesson. As explained by $\mathrm{Li} \mathrm{Li}$, "[the teacher] did not emphasize that there are many pieces, but you shouldn't count all the portions, you only count the number of portions in one piece" (LS5). In brief, the teachers were able to reflect from several perspectives at the later cycles of lesson study. In addition, they were also able to give many and more specific suggestions to improve the lesson at the later cycles of lesson study.

Descriptive reflection is the second level of reflection where teachers reflect and justify the incidents happened in the classroom. As shown in Figure 5, the percentages of utterances at this level were relatively low if compared with that of the first level: descriptive story; and third level: dialogic reflection. Moreover, most of the utterances at the descriptive reflection level were contributed by the teachers who taught the research lesson. They gave justification when the other members of the lesson study group commented on their research lesson. For instance, during the second LS reflection session, $\mathrm{Li} \mathrm{Li}$ critiqued that Rui Ern, the teacher who taught the research lesson only involved two pupils in an activity at the beginning of the lesson, "only two pupils played, other pupils did not have the chance to play" (Li Li, LS2). Rui Ern justified that "that part aimed to attract the pupils' attention, if too many pupils involved, three minutes [allocated for that activity would not be enough]" (LS2). Nonetheless, none of the teachers were able to reflect at the highest level of reflection: the critical reflection level throughout the five LS reflection sessions.

\section{DISCUSSION}

This study explored if there were any changes in teachers' reflection in terms of content and levels after participating in five lesson study cycles. The findings show that there were some slight and gradual changes in their reflection at the later cycles of lesson study. The four main changes include: (1) the teachers' reflection became more specific and in-depth; (2) the teachers' reflection about their pupils' learning became more focus and in-depth; (3) the teachers moved to reflect from their pupils' perspectives; and (4) the teachers were able to reflect at a higher level. 
The teachers' reflection became more in-depth at the later stages of lesson study. They analysed the relationship between pupils' learning with the instructional content and mathematical task. This finding shows that teachers would be able to understand the complex nature of teaching and learning as they reflect (Zeichner \& Liston, 1996).

The teachers' reflection about their pupils' learning became more in-depth at the later stages of the lesson study because they were able to pinpoint their pupils' misconceptions. Furthermore, the teachers became able to reflect from their pupils' perspectives at the later stages of lesson study, where they justified and made suggestions based on their pupils' learning and behaviour in the research lessons. It shows that the teachers have attained one of the unique criteria of lesson study because the main focus of lesson study is pupils' learning. As commented by Lewis (2002), lesson study gives the teachers "the eyes to see children" (p. 27). Being able to analyse the pupils' learning and reflect from the pupils' perspectives are very crucial. As the teachers understand the pupils' learning, behaviour and preference, they would be able to understand which types of teaching suit their pupils well. As a result, they would be able to adjust their teaching accordingly and help their pupils to learn well.

The teachers' reflection at the earlier LS cycle was predominantly at the descriptive story level. They merely described the incidents happened in the research lesson. Comparatively, at the later cycles, the teachers were able to reflect at the level of dialogic reflection. Teachers who reflected at this level were able to analyse the incidents happened in the research lesson from several perspectives and also to think of alternative ways to solve the issues (Hatton \& Smith, 1995). In this study, the teachers analysed from multiple perspectives when they discussed about the pupils' problem in determining the denominators of mixed number and improper fraction. They were able to view the problem from three different perspectives after much discussion among the lesson study group members, especially Rui Ern, Li Li and Kai Yan. Thus, this observation implies that the collaborative setting of lesson study could foster the teachers to reflect from several perspectives. The more they share the more ideas they have. 
However, it was rather disappointing to observe that the highest level of reflection achieved by the participating teachers in this study were dialogic reflection, the third level of reflection. None of them were able to reflect at the highest level of reflection, the critical reflection (Hatton and Smith,1995). Perhaps this finding is not surprising, as similar finding was reported by Myers (2012) that none of the participating teachers in his study reflected at critical reflection level. Most of the pre-service teachers achieved only up to dialogic reflection level. Myers (2012) argued that the most critical ability of reflection is being able to explore and consider events, actions and situation from different perspectives, recognizing and giving consideration to alternative explanations and to the views of others, which is reflection at the level of dialogic reflection.

Not only the framework suggested by Hatton and Smith (1995), critical reflection is also considered as the highest level of reflection in many other frameworks, such as frameworks suggested by Larrivee (2008), Jay and Johnson (2002), and Valli (1997). Teachers who reflect at this level are able to look at the problem from a broader perspective of historical, socio-political and moral. Hence, another reason that the teachers were not able to reflect at critical reflection level could be due to the context of lesson study. Lesson study focuses on studying the instructional materials and classroom teaching practices by examining the pupils' way of learning, thinking and understanding (Wang-Iverson \&Yoshida, 2005). Therefore, the teachers may not take into account the broader historical, socialcultural and/or political context when they were reflecting.

Even though the finding in this study indicates that changes in the teachers' reflection after the five lesson study cycles were gradual and little, it supports the claim by many earlier studies (e.g Burghes \& Robinson, 2009; Chiew, 2009; White \& Lim, 2007, 2008; Chikamori et al., 2013; Myers, 2012; Posthuma, 2012; Tosa, 2014). It also shows that the features of lesson study, which include collaborative and real classroom observation has promoted teachers' reflection. This finding supports the argument made by Myers (2012). Besides, the finding also supports the situated learning theory (Lave \& Wenger, 1991). As the teachers (novices) participated in the lesson study process, they carried out the lesson study cycles together with other novices and experts in the lesson study group, who were the other teachers and knowledgeable others in the lesson study group. 
The teachers communicated with the other members of the lesson study group and hence their reflection was improved.

Nevertheless, the effectiveness of lesson study in promoting the teachers' reflection might have affected by many factors. First, the number of LS cycles conducted. The teachers need to participate in multiple lesson study cycles as highlighted by Takahashi (2011) that the impact of lesson study on teacher is only visible after multiple cycles of lesson study. In this study, the changes were only visible during the fourth and fifth lesson study cycles. Thus, the impact of lesson study on the teachers' reflection might be more encouraging if the lesson study group conducted more lesson study cycles. However, due time constraint, we only managed to conduct five lesson study cycles.

Another factor that affecting the impact of lesson study on teachers' reflection is possibly the influence of the knowledgeable others as knowledgeable others play an important role in setting as role models for the teachers about how to reflect. Many other researchers (Chikamori et al., 2013; Myers, 2013, Hart \& Carriere, 2011) also contend that knowledgeable others play significant roles in helping the teachers to be more reflective in lesson study as they tend to ask more probing questions and give the teachers alternative perspectives in analyzing the lessons.

\section{IMPLICATIONS}

The findings of the study implied that it is feasible to enhance the teachers' reflection through lesson study process where the teachers collaboratively plan, observe and reflect on the research lesson. However, the teachers might need to conduct more than five lesson study cycles in order to see the result. This is because the impact of lesson study is gradual and takes several lesson study cycles to be visible. Furthermore, it is suggested to exclude critical reflection when assessing the levels of teachers' reflection in lesson study. It is because the main focus of lesson study is pupils' learning and how the teachers' teaching could impact the pupils' learning (WangIverson \& Yoshida, 2005). The teachers might not need to reflect at critical reflection level which requires them to consider broader historical, social and political context when they are reflecting upon the research lesson. 


\section{CONCLUSION}

This study aimed to explore the changes in teachers' reflection (if any) as the involved in five lesson study cycles. The findings revealed that the teachers' reflection gradually changed as they conducted the five lesson study cycles, where their reflection became more focused, their reflection about their pupils' learning became more in-depth, they became able to reflect from their pupils' perspectives and also reflect at higher levels of reflection. There were many factors that affected the teachers' change in reflection, especially the presence of knowledgeable others. This study exhibits some limitations. First, this study is a qualitative study that focus on only two lesson study groups. The findings may not be generalizable to the whole Malaysian context. Second, knowledgeable other plays an important role in lesson study. However, in this study, the knowledgeable others were lecturers and postgraduate student from a university. They are the mathematics content experts, but, they have limited experiences on the lesson study processes. Thus, their observation skills and commenting skills might be limited during the reflection sessions. This factor might be one of the reasons for the slow and gradual changes in teachers' reflection noticed during the reflection. Future the interaction between the knowledgeable others with the teachers in lesson study groups partly might have contributed to the teachers' reflection. Besides, in future it is suggested to explore to what extent the lesson study impact the teachers' reflection if the teachers voluntarily performed the lesson study.

\section{REFERENCES}

Aizan Yaacob, Walters, L. M., Ruzlan Md Ali, Sarimah Shaik Abdullah, \& Walters, T. (2014). Reflecting on Malaysian teacher trainees' journals. Malaysian Journal of Learning and Instruction, 11, 1-21.

Boon, P. Y. (2002). Amalan refleksi ke arah peningkatan profesionalime diri guru. Jurnal Institut Perguruan BahasaBahasa Antarabangsa (IPBA), 3(2), 102-109. Retrieved on Oct 9, 2012, from http://apps1.moe.gov.my/ipba/ResearchPaper/ journal/article11.pdf

Braun, J. A., \& Crumpler, T. P. (2004). The social memoir: An analysis of developing reflective ability in a pre-service methods course. Teaching and Teacher Education, 20, 59-75. 
Burghes, D., \& Robinson, D. (2009). Lesson study: Enhancing mathematics teaching and learning. CfBT Education Trust. Retrieved September 1,2014, from http://webfronter.com/ bexley/maths/menu2/Frontpage_files/Subject_Leaders/ images/2LessonStudy_v9_Web_.pdf

Cajkler, W., Wood, P., Norton, J., \&Pedder, D. (2014). Lesson study as a vehicle for collaborative teacher learning in a secondary school. Professional Development in Education, 40(4), 511529.

Chiew, C. M. (2009). Implementation oflesson study as an innovative professional development model among mathematics teachers (Unpublished doctoral dissertation), Universiti Sains Malaysia, Malaysia.

Chiew, C. M., Mohd Hasani Dali, Lim, C. S. (2016). Implementation of lesson study as as innovative professional development model among Malaysian school teachers. Malaysian Journal of Learning and Instruction, 13, 83-111.

Chikamori, K., Ono, Y., \& Rogan, J. (2013). A lesson study approach to improving a Biology lesson. African Journal of Research in Mathematics, Science and Technology Education, 17(1-2), 14-25.

Davis, E. A. (2006). Characterizing productive reflection among preservice elementary teachers: Seeing what matters. Teaching and Teacher Education, 22(3), 281-301.

Dewey, J. (1933). How we think: A restatement of the relation of reflective thinking to the educative process. Boston: D. C. Heath.

Fernandez, C., Cannon, J., \& Chokshi, S. (2003). A US-Japan lesson study collaboration reveals critical lenses for examining practice. Teaching and Teacher Education, 19, 171-185.

Glazer, C., Abbott, L., \& Harris, J. (2004). A teacher-developed process for collaborative professional reflection. Reflective Practice, 5(1), 33-46.

Hart, L. C., \& Carriere, J. (2011). Developing the habits of mind for a successful lesson study community. In L. C. Hart, A. S. Alston, \& A. Murata (Eds.), Lesson study research and practice in mathematics education (pp. 27-38). Netherlands: Springer.

Hassett, M. F. (2000). What makes a good teacher? Adventures in Assessment, 12, 9-12. 
Hatton, N., \& Smith, D. (1995). Reflection in teacher education: Towards definition and implementation. Teaching and Teacher Education, 11(1), 33-49.

Hindin, A., Morocco, C. C., Mott, E. A., \& Aguilar, C. M. (2007). More than just a group: Teacher collaboration and learning in the workplace. Teachers and Teaching: Theory and Practice, 13(4), 349-376.

Jay, J. K., \& Johnson, K. L. (2002). Capturing complexity: A typology of reflective practice for teacher education. Teaching and Teacher Education, 18, 73-85.

Larrivee, B. (2008). Development of a tool to assess teachers' level of reflective practice. Reflective Practice, 9(3), 341-360.

Lasut, M. (2013). Effect of implementation lesson study to improve students' learning achievement in Calculus I of mathematics department. Journal of Education and Practice, 4(20), 182188.

Lave, J., \& Wenger, E. (1991). Situated learning: Legitimate peripheral participation. Cambridge: University of Cambridge Press.

Lewis, C. (2002). Lesson study: A handbook of teacher-led instructional change. Philadelphia, PA: Research for Better Schools.

Malaysian Ministry of Education (1999). Preparation of Teaching and Learning Record. [Professional Circular No. 3]. Kuala Lumpur, Malaysia.

Mak, W. F. (2016). Effect of lesson study incorporating phasebased instruction on Form one students' achievement and learning motivation in Geometry. Unpublished master's thesis, Universiti Sains Malaysia, Malaysia.

Meyer, R. D., \& Wilkerson, T. L. (2011). Lesson study: The impact on teachers' knowledge for teaching mathematics. In L. C. Hart, A. S. Alston, \& A. Murata (Eds.), Lesson study research and practice in mathematics education (pp. 15-26). Dordrecht: Springer.

McIntyre, D. (1993). Theory, theorizing and reflection in initial teacher education. In J. Calderhead \& P. Gates (Eds.), Conceptualizing reflection in teacher development (pp. 3952). London: The Falmer Press.

Myers, J. (2012). The effects of lesson study on classroom observations and perceptions of lesson effectiveness. The Journal of Effective Teaching, 12(3), 94-104. 
Nooreiny Maarof (2007). Telling his or her story through reflective journals. International Education Journal, 8(1), 205-220.

O'Sullivan, M. C. (2002). Action research and the transfer of reflective approaches to in-service education and training (INSET) for unqualified and underqualified primary teachers in Namibia. Teaching and Teacher Education, 18, 523-539.

Ong, E. G. (2010). Changes in mathematics teachers' questioning techniques through the lesson study process. Unpublished doctoral dissertation, Universiti Sains Malaysia, Malaysia.

Posthuma, B. (2012). Mathematics teachers' reflective practice within the context of adapted lesson study. Pythagoras, 33(3), 1-17. Retrieved May 8, 2013, from http://dx.doi.org/10.4102/ pythagoras.v33i3.140

Scales, P. (2008). The reflective teacher. In Teaching in the lifelong learning sector (pp. 7-26). Berkshire: Open University Press.

Siti Mistima Maat, \& Effandi Zakaria. (2010). An exploration of mathematics teachers' reflection on their teaching practices. Asian Social Science, 6(5), 147-152.

Suh, J., \& Seshaiyer, P. (2014). Examining teachers' understanding of the mathematical learning progression through vertical articulation during lesson study. Journal of Mathematics Teacher Education, 1-23.

Suratno, T. (2012). Lesson study in Indonesia: An Indonesia University of Education experience. International Journal for Lesson and Learning Studies, 1(3), 196-215.

Suratno, T., \& Iskandar, S. (2010). Teacher reflection in Indonesia: Lessons learnt from a lesson study program. US-China Education Review, 7(12), 39-48.

Suraya Sulyman. (2005). English as a second language teachers' reflections on in-service professional and self-development. Unpublished doctoral dissertation, Universiti Putra Malaysia, Malaysia.

Takahashi, A. (2011). Jumping into lesson study- Inservice mathematics teacher education. In L. C. Hart, A. Alston, \& A. Murata (Eds.), Lesson study research and practice in mathematics education (pp. 79-82). New York: Springer.

Takahashi, A. (2014). The role of the knowledgeable other in lesson study: Examining the final comments of experienced lesson study practitioners. Mathematics Teacher Education \& Development, 16(1), 4-21. 
Tee, Y. J. (2007). Amalan pemikiran reflektif dalam kalangan guru matematik sekolah menengah. Unpublished Master's thesis, Universiti Putra Malaysia, Malaysia.

Tosa, S. (2014, November). Identifying levels of teacher reflection during post-lesson discussions through lesson study. Paper presented at World Association of Lesson Studies International Conference, Bandung, Indonesia.

Valli, L. (1997). Listening to other voices: A description of teacher reflection in the United States. Peabody Journal of Education, 72(1), 67-88.

Wang-Iverson, P., \& Yoshida, M. (Eds.). (2005). Building our understanding of lesson study. Philadelphia: Research for Better Schools.

White, A. L., \& Lim, C. S. (2007). Lesson study in a global world. In C. S. Lim, S. Fatimah, G. Munirah, M. Y. Hashimah, W. L. Gan, \& T. Y. Hwa (Eds.), Meeting the challenges of developing quality mathematics education (pp. 567-573). Penang, Malaysia, Universiti Sains Malaysia.

White, A. L., \& Lim, C. S. (2008). Lesson study in Asia Pasific classrooms: Local responses to a global movement. ZDM The International Journal of Mathematics Education, 40(6), 915925.

Yoshida, M. (2012). Mathematics lesson study in the United States. International Journal for Lesson and Learning Studies, 1(2), $140-152$.

Zeichner, K. \& Liston, D. (1996). Reflection teaching. Erlbaum Publisher. 